\title{
DYNAMIC CHANGE OF COMPOSITION AND FUNCTIONS OF FLORA ADAPTING TO RAPID URBANIZATION: A CASE STUDY OF HANGZHOU, CHINA
}

\author{
YU, H. F. ${ }^{1}-$ GAO, W. J. ${ }^{2}-$ ZHANG, J. ${ }^{1}-$ YANG, G. F. ${ }^{1}-$ WU, Y. Q. ${ }^{3}-$ LU, Y. J. ${ }^{1 *}$ \\ ${ }^{I}$ Zhejiang University City College, Hangzhou 310015, China \\ (e-mail: yuhf@zucc.edu.cn (Yu,H.F.); zhangjia@zucc.edu.cn (Zhang, J.); \\ gf.yang@zucc.edu.cn (Yang, G. F.)) \\ ${ }^{2}$ Faculty of Environment al Engineering, The University of Kitakyushu, Kitakyushu 808-0135, \\ Japan \\ (e-mail: gaoweijun@me.com(Gao,W.J.))
}

${ }^{3}$ College of Civil Engineering and Architecture, Zhejiang University, Hangzhou 310058, China (e-mail: arc_wyq@163.com $(W u, Y . Q)$.

"Corresponding author

e-mail:luyijun@zucc.edu.cn; phone: +86-158-5815-3276

(Received $7^{\text {th }}$ May 2021; accepted $12^{\text {th }}$ Aug 2021)

\begin{abstract}
Rapid urbanization has changed urban ecological environments and affected local biodiversity. An analysis of the existing literature examining changes in urban biodiversity may help with urban planning and biodiversity conservation. The present paper analysed the dynamic change of plant diversity in Hangzhou over the past four decades of rapid urbanization. It was found that although the number of plant species increased from 1,565 in 1981 to 1,799 in 2020, 101 plant species were lost. At the same time, 18 invasive species of plants and 52 ornamental plant species were acquired, with the largest increase observed in perennial herbs as a result of urban greening. A comparison of the respective Ellenberg's Indicator Values (EIV) of lost and acquired species reveals a larger increase in the number of species for sun plants than for shade plants. The latter did not increase with the rapid increase in urban green areas. A significant increase in the number of thermophilous plant species was observed, which is closely related to global warming and the heat island effect in cities. The number of aquatic plants also increased due to urban wetland landscaping. Prioritizing land conservation in urban planning is more conducive to producing and maintaining stable urban ecosystems and practicing sustainable urban development.
\end{abstract}

Keywords: plant diversity, Ellenberg's Indicator Value, ecotype, acquired species, endangered plant, urban ecosystems, urban planning

\section{Introduction}

Urban areas are the ecosystems that have been subjected to the highest degree of control by humankind (Grimm et al., 2000); its ecological processes are controlled by the complex interaction of both social-economic factors and natural environmental factors (Kaye et al., 2006), of which human designs and activities have substantially changed localized settings. This is particularly true in recent decades when rapid urbanization has led to significant changes in urban environments. Such indicators of change include the high concentrations of gaseous, granular and photochemical pollutants in the air (Zhang et al., 2012), impaired descent of water due to ground hardening (Vico et al., 2013), soil compaction (Bijoor et al., 2012), high concentrations of heavy metals in soil (Chen et al., 2013), habitat fragmentation (Angold et al., 2006), nitrogen deposition, the urban heat island effect, high concentrations of $\mathrm{CO}_{2}$ (Lovett et al., 2000; Gregg et al., 2003; Loughner et al., 2012), and human interventions (Niinemets et al., 2008), amongst others. 
As a result, urban flora has evolved, with significant dynamic changes found in plant diversity (Pickett et al., 2001; Sukopp, 2002; McKinney, 2006; Kowarik, 2011).

Urbanization is a long process, during which urban plants may gradually develop characteristics that allow them to adapt to their environment. Therefore, an analysis of changes in urban plant diversity in different periods will inform our understanding of the relationship between urbanization and the change in floristic composition, and the driving forces behind the change in floristic composition. This study will be helpful for urban development and planning. There have been studies in Europe investigating urban changes in floristic composition over long periods of time (Landolt, 2000; Kent et al., 2001; Chocholouskova and Pyšek, 2003; Sal'nikov and Pilipenko, 2005; Lososová and Simonová, 2008). One study of plant changes in Brussels conducted over 50 years (Godefroid, 2001) found that although the number of plant species had not changed significantly, the number of alien species had increased significantly. Human activities have changed the distribution area of many plant species; for instance, some species growing on farmlands and woodlands or in swamps either decreased or disappeared altogether. One piece of research on plant changes in Frankfurt over a period of 200 years showed that the number of species is decreasing as urbanization increases. The most important driving forces behind species loss are the use of fertilizers and herbicides, the abandonment of woodlands and pastures, and the destruction of wetlands. Any plant species that have increased are typically introduced due to the ornamental function of gardens (Gregor et al., 2012). Although there have been studies on the plant change response to urbanization, not all such studies are comprehensive and the historical plant data collected in these studies are not complete for various reasons (SudnikWojcikowska, 1987). Very few relevant studies can be found outside Europe as there is a lack of historical data available and only a small number of cities have historical records of their flora. This has led to difficulties in studying urban plant diversity over longer time periods. This is particularly so in China, which lacks systematic and complete data historical records on urban plants. China is currently in the midst of rapid urbanization, with its urban plant diversity having already changed in terms of composition and function. An in-depth understanding of the influence of rapid urbanization on urban plant diversity may have referential value for the future of urban planning and regional development.

Ellenberg indicator values (EIV) record the adaptation for all plants in Western Central Europe on a scale of 1-9 based on seven ecological factors: light, temperature, moisture, soil reaction, soil fertility, continentality, and salinity. These values are widely used to describe trends in the changing ecological adaptability of plants in the urban areas of Central Europe (Godefroid, 2001; Gregor et al., 2012; Domina et al., 2018; Salinitro et al., 2019). Based on the study of plant diversity changes in some cities in this region, it is found that urbanization will lead to the increase of shade-tolerant, thermophilic, and fertilizer-loving plant species. Such changes are closely related to the increase in green urban spaces, urban temperature, and nitrogen deposition. Pärtel et al. (1996) determined the habitat range of 14 plant communities in Estonia according to the Ellenberg indicator values (EIV) of vascular plants in the city. Besides Europe, no other region has complete Ellenberg indicator values (EIV), so it is not possible to compare different regions. In China, there is a lack of systematic research on the ecological adaptation of plants. Combined with the current research results, Ellenberg indicator values (EIV) of five ecological factors (including light, temperature, moisture, soil reaction and soil fertility), for more than 4000 plant species were recorded for more than 4000 plant species (Song 
et al., 2013). The first two indicators are related to climate, whilst the last three are related to soil properties.

In the last four decades, the city of Hangzhou conducted two comprehensive surveys on urban plant diversity on two occasions (1981 and 2017) and compiled plant diversity inventories. After 2017, scholars went on to identify more plant species in the region and further generate relevant data. Due to these efforts, Hangzhou has become a perfect case for studying the relationship between rapid urbanization and plant diversity evolution. The present paper carries out an analysis of the changes in floristic composition over the past four decades in Hangzhou to understand: (a) the changes in plant diversity and composition in Hangzhou's rapid urbanization and their driving forces; (b) the changes in introduced plants and rare and endangered plants because of rapid urbanization, as well as the role urbanization plays in composition of urban plant diversity; (c) the changes in plant ecotypes and their ecological demand by using Ellenberg's Indicator Values (EIV). This analysis is expected to have reference value for future urban planning.

\section{Materials and Methods}

\section{The study area}

Hangzhou $\left(118^{\circ} 20^{\prime}-120^{\circ} 37^{\prime}, 29^{\circ} 11^{\prime}-30^{\circ} 34^{\prime}\right)$, the capital city of Zhejiang Province, is in East China's Yangtze River Delta area. The city has witnessed rapid economic development and urbanization since 1980. It covers a total area of 16.85 thousand $\mathrm{km}^{2}$, among which urban areas cover a total of 8.289 thousand $\mathrm{km}^{2}$. Over the last 40 years, its population has soared, with its permanent resident population growing from 5.2073 million in 1981 to 10.36 million in 2020. The city is famous for its business and tourism, with its total GDP ranking $9^{\text {th }}$ in China. The annual average temperature ranges from $15.8^{\circ} \mathrm{C}$ to $18.5^{\circ} \mathrm{C}$. The city receives an average annual rainfall of between 1100 and $1600 \mathrm{~mm}$. The highest point in the city has an altitude of $1787 \mathrm{~m}$. The forest coverage rate in the city totals $66.8 \%$. During the city's rapid transformation, Hangzhou's zoning and areas have seen many changes. At present, there are 10 districts in Hangzhou, as Fuyang City and Lin'an City merged into Hangzhou as urban districts in 2015 and 2017, respectively. However, in the 1980s, the investigation of plant species in Hangzhou did not cover these two areas. In order to ensure a consistent research area, the plant data for Lin'an District and Fuyang District are not included in the present paper (Fig. 1).

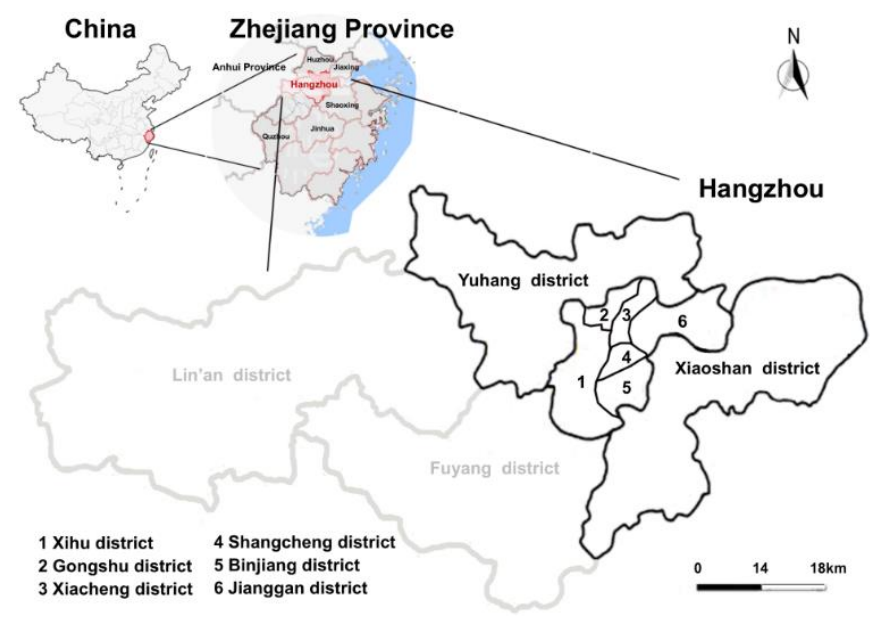

Figure 1. The study area and scope 


\section{Data sources and processing}

\section{Data sources}

Data on the number of plant species are mainly derived from HBH (1982) and Yu et al. (2017). The numbers of newly identified plant species and their distribution in the region in the years 2017-2020 are also collected (Chen et al., 2019; Ding et al., 2019; Li et al., 2021) to form the dataset for 2020. In addition, the classification of several plant species is adjusted by referring to Flora of China (Wu et al., 2013) and the latest research achievements in plant classification (Xie et al., 2019; Chen et al., 2021; Chi et al., 2021). Hence, the plant inventories in the two periods are obtained.

\section{Flora analysis}

The floras are classified in different periods according to the areal-types of Chinese genera of seed plants (Wu, 1991) and pteridophyte (Zang, 1998). Invasive plant species are determined according to Ma (2013) and Yan et al. (2019). Meanwhile, any rare or endangered plants and national key preserved wild plants are determined by Fu (1992) and NFA (1999).

\section{Growth form analysis}

By referring to the plant growth form classification designed by Song et al. (2015), the growth forms of plant species are simplified into two levels. Level-I growth forms include Tree (T), Shrub (S), Herb (H), Vine (V) and Epiphyte (Ep). Level-II growth forms of Tree, Shrub and Vine are further divided into Evergreen Tree (ET) and Deciduous Tree (DT), Evergreen Shrub (ES) and Deciduous Shrub (DS), Evergreen Vine (EV) and Deciduous Vine (DV) according to whether they are deciduous or not, respectively. Herb is further divided into Annual Herb $(\mathrm{AH})$ and Perennial Herb $(\mathrm{PH})$ according to the life cycle.

\section{Ecotype determination}

According to the Ellenberg Indicator Value (Ellenberg et al., 1991) and Song et al. (2013), all of the ecological factors were classified as one of nine levels with numerical ranges also given. Due to the lack of systematic studies looking into the ecological value of plants in China, we selected five ecological factors including light, temperature, moisture, soil reaction and soil fertility to classify plants in terms of indicator values, which were recorded by Song et al. (2013) (Table 1). As EIVs for some plant species were not available in the literature, the indices were calculated by referencing known species growing in the same habitat.

Table 1. Gradations of plant ecological indicator values (Song et al., 2013)

\begin{tabular}{|c|c|c|c|c|c|c|c|c|c|}
\hline Levels & 1 & 2 & 3 & 4 & 5 & 6 & 7 & 8 & 9 \\
\hline Light & Full shadow & $\begin{array}{c}\text { Between } 1 \\
\text { and } 3\end{array}$ & Shadow & $\begin{array}{c}\text { Between } \\
3 \text { and } 5\end{array}$ & $\begin{array}{c}\text { Half } \\
\text { shadow }\end{array}$ & $\begin{array}{c}\text { Between } \\
5 \text { and } 7\end{array}$ & Half light & Light & Full light \\
\hline Temperature & Frigid & Sub-frigid & $\begin{array}{c}\text { Cool } \\
\text { temperate }\end{array}$ & $\begin{array}{c}\text { Mid- } \\
\text { temperate }\end{array}$ & $\begin{array}{c}\text { Warm- } \\
\text { temperate }\end{array}$ & $\begin{array}{c}\text { Sub-warm } \\
\text { torrid }\end{array}$ & $\begin{array}{l}\text { Warm- } \\
\text { torrid }\end{array}$ & $\begin{array}{l}\text { Sub- } \\
\text { torrid }\end{array}$ & Torrid \\
\hline Moisture & $\begin{array}{c}\text { Super } \\
\text { xerophyte }\end{array}$ & $\left|\begin{array}{c}\text { Between } 1 \\
\text { and } 3\end{array}\right|$ & Xerophyte & $\begin{array}{l}\text { Between } \\
3 \text { and } 5\end{array}$ & Mesophyte & $\begin{array}{c}\text { Between } \\
5 \text { and } 7\end{array}$ & Hygrophyte & $\begin{array}{c}\text { Between } \\
7 \text { and } 9\end{array}$ & Hepophyte \\
\hline Soil reaction & $\begin{array}{l}\text { Extremely } \\
\text { acidic soil }\end{array}$ & $\begin{array}{c}\text { Between } 1 \\
\text { and } 3\end{array}$ & Acidic soil & $\begin{array}{l}\text { Between } \\
3 \text { and } 5\end{array}$ & $\begin{array}{c}\text { Weakly } \\
\text { Acidic soil }\end{array}$ & $\begin{array}{c}\text { Between } \\
5 \text { and } 7\end{array}$ & $\begin{array}{c}\text { Neutral } \\
\text { soil }\end{array}$ & $\begin{array}{c}\text { Between } \\
7 \text { and } 9\end{array}$ & Alkaline soil \\
\hline Soil fertility & $\begin{array}{c}\text { Extremely } \\
\text { poor soil }\end{array}$ & $\mid \begin{array}{c}\text { Between } 1 \\
\text { and } 3\end{array}$ & Poor soil & $\begin{array}{c}\text { Between } \\
3 \text { and } 5 \\
\end{array}$ & $\begin{array}{l}\text { Mid-rich } \\
\text { soil }\end{array}$ & $\begin{array}{c}\text { Between } \\
5 \text { and } 7\end{array}$ & Rich soil & $\begin{array}{c}\text { Super-rich } \\
\text { soil }\end{array}$ & $\begin{array}{c}\text { Extremely } \\
\text { rich soil }\end{array}$ \\
\hline
\end{tabular}




\section{Data calculation and analysis}

The data were statistically analyzed through Excel 2010 software and difference significance analysis conducting using SPSS17.0 software (Wu et al., 2014).

\section{Results}

\section{Changes in floristic composition}

In 2020, 1799 species of plants were registered in the research area, belonging to 184 families and 845 genera. 234 new species belonging to 6 families and 106 genera were found, which is a significant increase compared to 1981 (Fig. 2). The most common species found were in Gramineae, followed by Compositae, Cyperaceae, Leguminosae, and Rosaceae, respectively. The top ten families in terms of amount did not change between 1981 and 2020; however, the number of species of all the families (except Gramineae) increased over this period, with the largest increases found in Compositae, Cyperaceae and Liliaceae (Fig. 3).

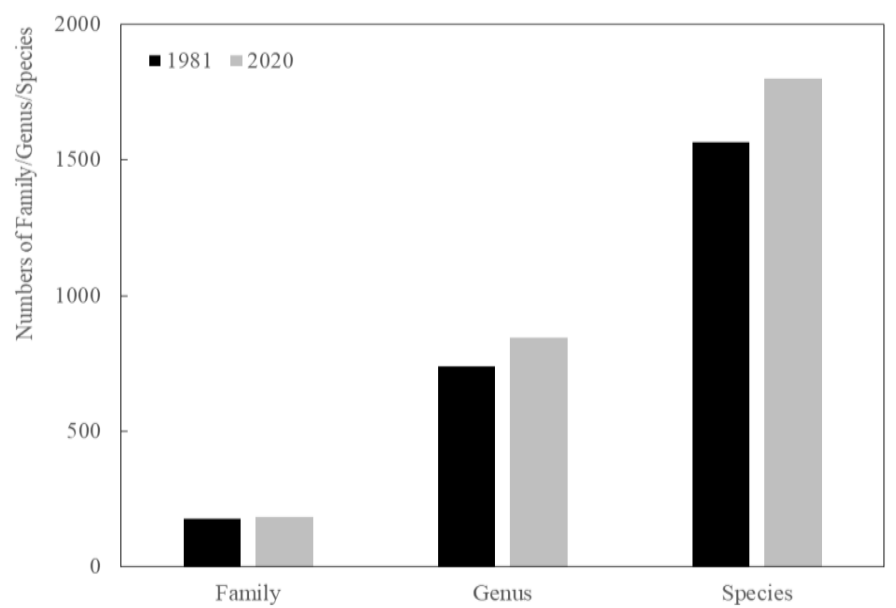

Figure 2. The number of plant families, genera and species in 1981 and 2020

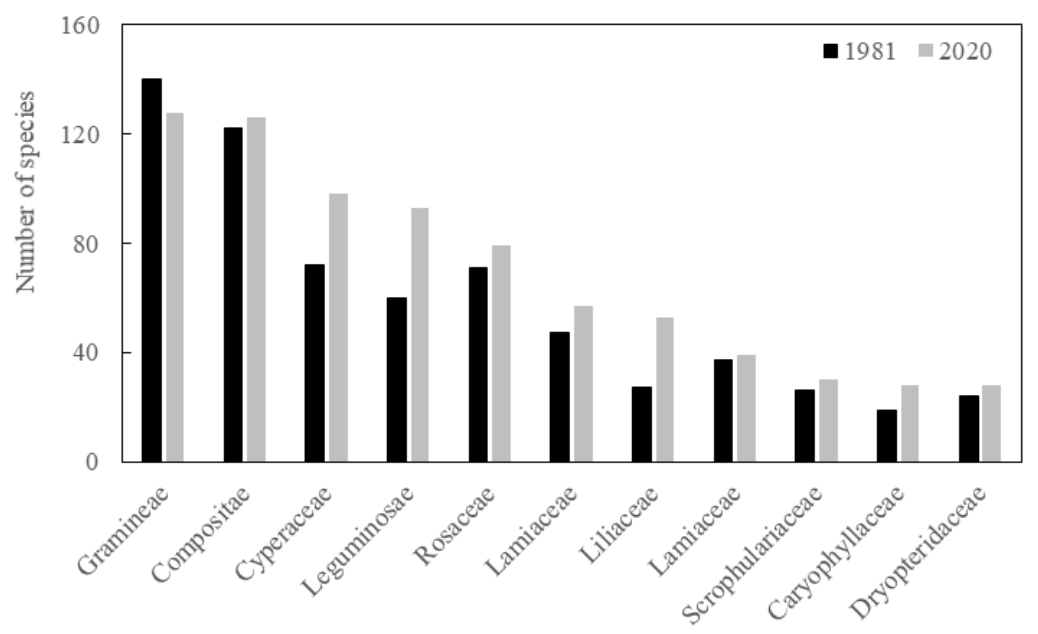

Figure 3. The top ten families with the most species in 1981 and 2020 
Although 101 species of plants were lost between 1981 and 2020, 438 new species were found. 1386 species of plants were recorded in both periods and whilst 11 genera of plants were lost between 1981 and 2020, 117 new genera were found. In total, 728 genera of plants were recorded in both periods (Fig. 4). Some species were introduced through urban greening, leading to enriched plant diversity in the city. Statistics show that 433 species of ornamental plants were registered in 2020, an increase of 52 from 1981 (Table 2).

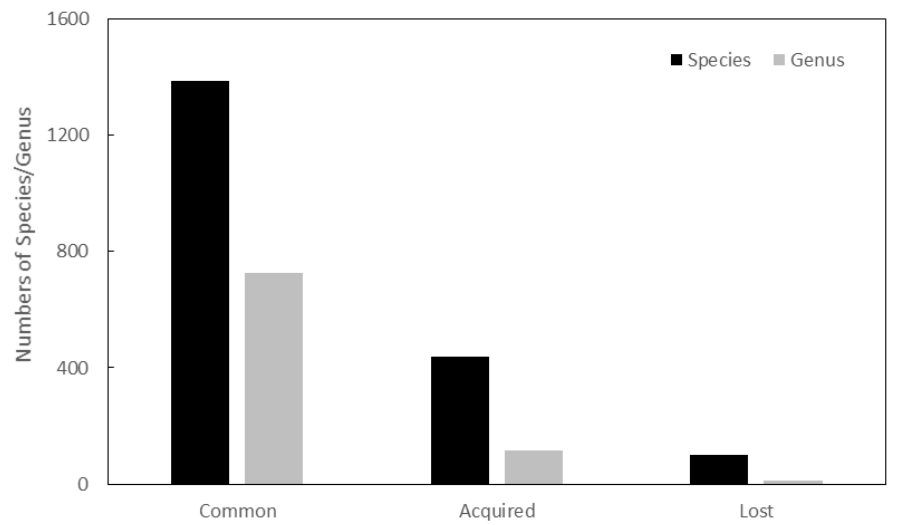

Figure 4. The number of species and genera of common, acquired, and lost plants in 1981 and 2020

Table 2. Changes in plant growth forms between 1981 and 2020

\begin{tabular}{|c|c|c|c|c|c|}
\hline \multicolumn{2}{|c|}{ Growth form } & \multicolumn{2}{|c|}{ All plants } & \multicolumn{2}{|c|}{ Ornamental plants } \\
\hline Level-I & Level-II & 1981 & 2020 & 1981 & 2020 \\
\hline \multirow{2}{*}{ Tree $(\mathrm{T})$} & $\begin{array}{l}\text { Evergreen Tree } \\
\text { (ET) }\end{array}$ & 72 & 85 & 40 & 43 \\
\hline & $\begin{array}{l}\text { Deciduous Tree } \\
\text { (DT) }\end{array}$ & 145 & 164 & 72 & 75 \\
\hline \multirow{2}{*}{ Shrub (S) } & $\begin{array}{l}\text { Evergreen Shrub } \\
\text { (ES) }\end{array}$ & 83 & 100 & 56 & 58 \\
\hline & $\begin{array}{c}\text { Deciduous Shrub } \\
\text { (DS) }\end{array}$ & 131 & 153 & 45 & 50 \\
\hline \multirow{2}{*}{ Vine (V) } & $\begin{array}{l}\text { Evergreen Vine } \\
\text { (EV) }\end{array}$ & 27 & 38 & 7 & 9 \\
\hline & $\begin{array}{l}\text { Deciduous Vine } \\
\text { (DV) }\end{array}$ & 105 & 128 & 7 & 8 \\
\hline \multirow[t]{2}{*}{ Herb $(\mathrm{H})$} & $\begin{array}{c}\text { Perennial Herb } \\
(\mathrm{PH})\end{array}$ & 874 & 979 & 130 & 164 \\
\hline & Annual Herb (AH) & 126 & 149 & 24 & 26 \\
\hline \multicolumn{2}{|c|}{ Epiphyte (E) } & 2 & 3 & 0 & 0 \\
\hline \multicolumn{2}{|c|}{ Total } & 1565 & 1799 & 381 & 433 \\
\hline
\end{tabular}

\section{Comparison of flora}

A comparison of flora in 1981 and 2020 reveals that the 117 acquired genera of plants belong to 14 areal types. 20 genera were found to belong to the Pantropic type, which is the most common, followed by 14 genera belonging to the Old World Temperate type. The 11 lost plant genera belong to 7 areal types, including 2 belonging to the Pantropic type and 2 to the North Temperate type (Fig. 5). 


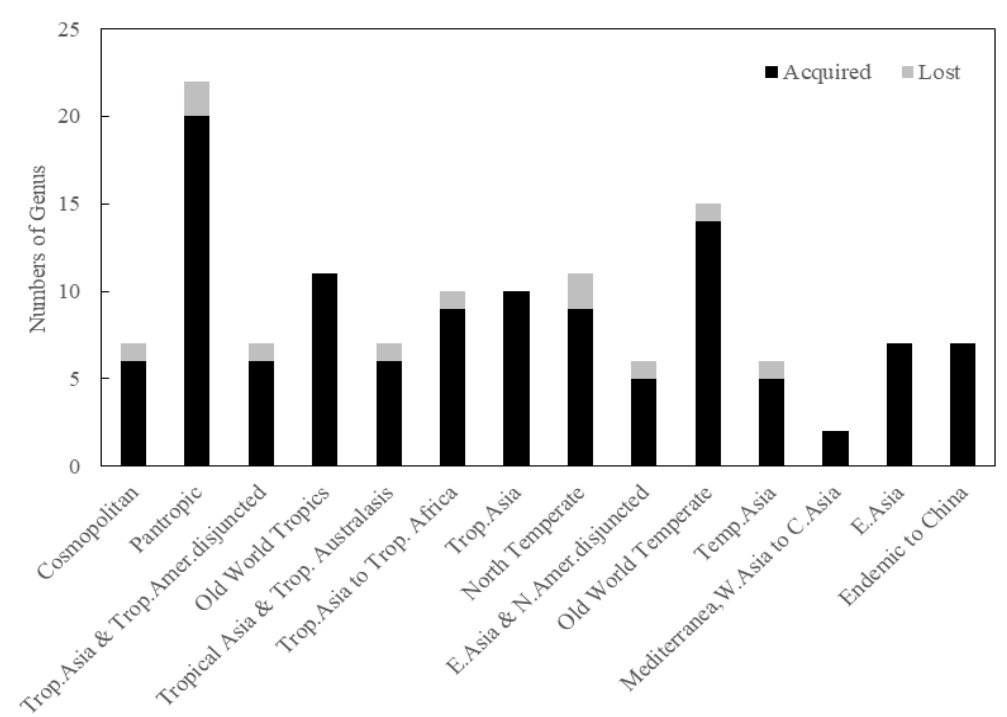

Figure 5. The areal types of lost and acquired plant genera in 1981 and 2020

70 invasive species were found in 2020, which is 18 more than in 1981. Most of the invasive species are from Tropical America, with 36 registered in 1981 and 47 in 2020, accounting for $61.1 \%$ of the total number of new invasive plant species. Only one invasive plant from Oceania was recorded (Fig. 6).

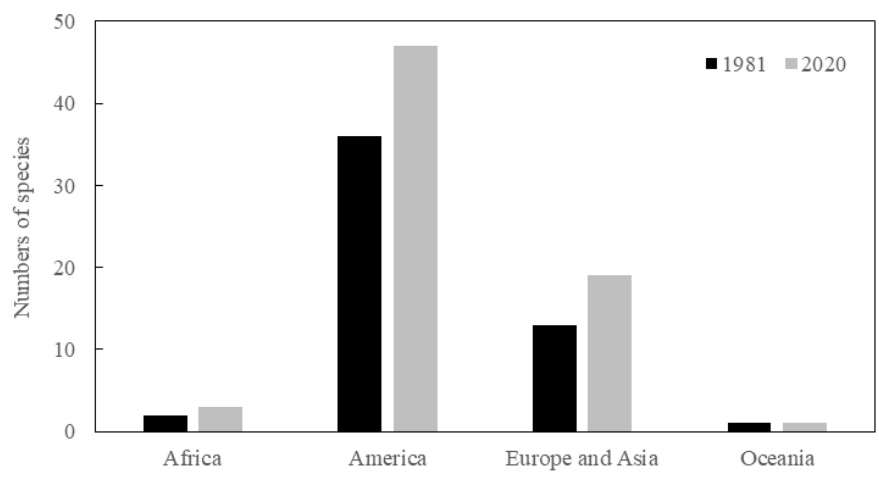

Figure 6. The number and source of invasive plants in 1981 and 2020

In 2020, the research area recorded a total of 20 rare or endangered plants and national key preserved wild plant species. Compared to 1981, 15 species were found in new distribution sites. However, the historical distribution sites of 15 species had disappeared. The number of existing distribution sites increased for 9 species, including 3 species that were newly found in the research area. The number of existing distribution sites decreased for 8 species, including Pterygopleurum neurophyllum which disappeared from the research area (Table 3).

\section{Changes of growth form and ecotype}

Perennial herbs have the largest number of species among all plants (979), followed by deciduous trees (164). Compared with 1981, the growth form of all plants in the 
research area saw an increase in 2020. The largest increase was found in perennial herbs, which had 105 new types. In 2020, the number of common ornamental plant species in the research area increased by 52 compared with 1981, including 34 perennial plants, which account for $65.38 \%$ of the total increase (Table 2).

Table 3. The number of distribution sites of rare and endangered plants and national key preserved wild plants

\begin{tabular}{c|c|c|c|c|c}
\hline Species & Common English names & HDS & VS & NDS & EDS \\
\hline Ardisia violacea & -- & 2 & 1 & 0 & 1 \\
Brachystachyum densiflorum & -- & 1 & 1 & 1 & 1 \\
Changium smyrnioides & Radix changii & 5 & 0 & 4 & 9 \\
Changnienia amoena & -- & 0 & 0 & 1 & 1 \\
Celastrus orbiculatus & Oriental bittersweet & 1 & 0 & 0 & 1 \\
Ceratopteris thalictroides & Water fern & 0 & 0 & 3 & 3 \\
Emmenopterys henryi & -- & 1 & 1 & 1 & 1 \\
Fagopyrum dibotrys & Wild buckwheat & 5 & 1 & 8 & 12 \\
Gelidocalamus marmorea & -- & 0 & 0 & 2 & 2 \\
Glycine soja & Wild soybean & 4 & 3 & 15 & 16 \\
Isoetes sinensis & -- & 4 & 4 & 2 & 2 \\
Machilus chekiangensis & -- & 2 & 1 & 0 & 1 \\
Mosla hangchowensis & -- & 7 & 4 & 1 & 4 \\
Ormosia henryi & -- & 6 & 4 & 1 & 3 \\
Phoebe chekiangensis & -- & 4 & 1 & 3 & 6 \\
Pteroceltis tatarinowii & Wingceltis & 1 & 1 & 1 & 2 \\
Pterygopleurum neurophyllum & -- & 1 & 1 & 0 & 0 \\
Trapa incisa & Water chestnut & 5 & 3 & 1 & 3 \\
Yulania cylindrica & -- & 1 & 1 & 1 & 1 \\
Zelkova schneideriana & Chinese Zelkova & 4 & 2 & 0 & 2 \\
\hline
\end{tabular}

HDS: historical distribution sites, the number of plant distribution sites recorded in historical documents; VS: vanishing sites, the number of plant distribution sites recorded in the historical documents for plants not found in the 2020 survey; NDS: new distribution sites, the number of newly discovered plant distribution sites in 2020; EDS: existing distribution sites, the total number of existing plant distribution sites

A comparison of the ecotype of acquired and lost species reveals that in terms of light demand, more lost species are found to be between Half shadow and Half light (Level 5-7), whilst most of the acquired species are found between Half light and Full light (Level 7-8), increasing by 106 and 109, respectively. Together they account for $49.1 \%$ of the total increase. A large increase of 160 species was also found between Shadow and Half shadow (Level 3-5), accounting for 36.5\% of the total increase (Fig. 7A). Torrid plants have also seen a substantial increase. Plants between Warm-temperate and Sub-torrid (Level 5-8) account for $84.5 \%$ of the total increase. A similar trend is found for lost species. However, four Sub-frigid (Level 2) plants were lost (Fig. 7B). In terms of moisture, there was a reasonable increase in plant species belonging to Mesophyte (Level 5-6), accounting for $69.6 \%$ of the total increase. Xerophyte plants (Level 3-4) and Hepophyte plants (Level 9) also increased sharply (Fig. 7C). Plants with weakly acid soil (Level 5-6) experienced the largest increase, whilst plants with alkaline soil (Level 8) saw a mild increase. More lost plants were found to be in neutral soil (Level 7) (Fig. 7D). Plants with mid-rich soil (Level 5-6) have been acquired and lost the most, accounting for $74.3 \%$ and $63 \%$ of their respective totals. Plants with poor soil (Level 3-4) were also acquired mildly (Fig. 7E). 


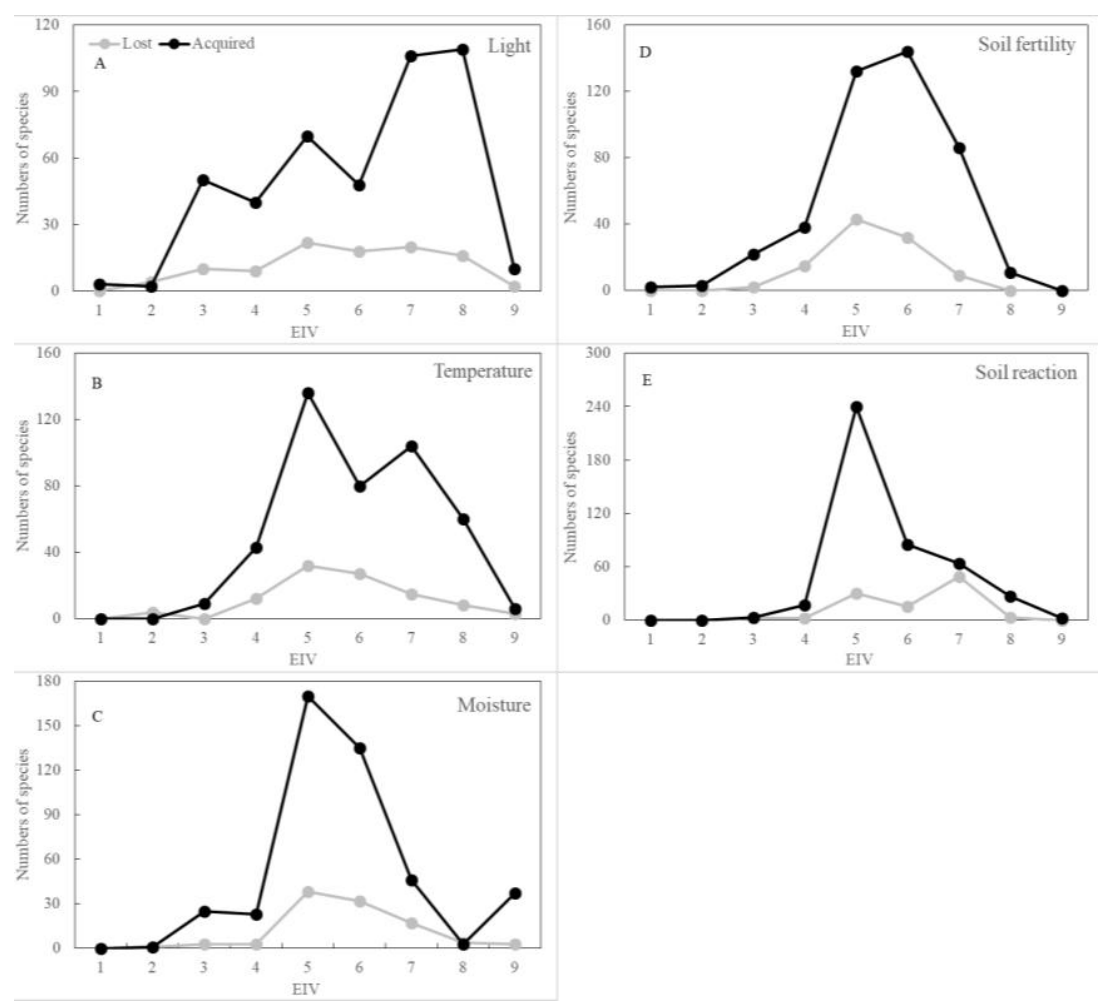

Figure 7. EIV for acquired and lost plants in 1981 and 2020

The acquired species prefer higher light, higher temperature and higher soil fertility and there were significant differences compared with those of the lost species. However, there was no significant difference in water demand. In response to the soil reaction, the acquired species prefer acidic soil (Table 4).

Table 4. Comparison of ecological requirements of acquired and lost plants in 1981 and 2020

\begin{tabular}{c|c|c|c}
\hline Ecological factor & Lost & Acquired & Significance acquired/lost \\
\hline Light & $5.75 \pm 1.74$ & $6.23 \pm 1.78$ & $* *$ \\
Temperature & $5.69 \pm 1.43$ & $5.98 \pm 1.35$ & $*$ \\
Moisture & $5.76 \pm 1.21$ & $5.62 \pm 1.31$ & - \\
Soil reaction & $6.17 \pm 1.07$ & $5.40 \pm 0.83$ & $* *$ \\
Soil feritily & $5.30 \pm 0.89$ & $5.55 \pm 1.22$ & $*$ \\
\hline
\end{tabular}

** Significance of t-test $\mathrm{p}<0.01 ; *$ Significance of t-test $0.01<\mathrm{p}<0.05 ;-$ Significance of $\mathrm{t}$-test $\mathrm{p}>0.05$

\section{Discussion}

\section{Significance of complete historical plant data}

Literature on flora can be of great help in analyzing changes in plant diversity and trends in biodiversity development (Knapp et al., 2010). There have been a number of studies conducted looking at the effects of long-term urban environmental changes on biodiversity, such as those studying periods of over 100 years (Fudali, 1995) or 200 years (Gregor et al., 2012). The study on urban biodiversity with the longest time span was conducted by Knapp et al. (2010), which studied urban plant functional characteristics in central Europe over nearly three centuries and analyzed the ecological characteristics of 
urban plants in different time periods. The study proved that plants could adapt and respond to urbanization and urban environments. Meanwhile, biodiversity development trends can differ across different time spans. For example, over a shorter span, urban plant diversity may improve (Grimm et al., 2008), which is similar to our findings; however, Godefroid's study of Brussels over nearly 50 years (Godefroid, 2001) revealed a trend of decreasing plant diversity. Whilst plant diversity gradually decreases over longer time spans (Tait et al., 2005), Salinitro et al.'s study (2019) arrived at an opposite finding, which may be due to the complexity of the factors affecting plant diversity evolution. Changes in the urban environment brought about by rapid urbanization such as ground hardening and increased concentrations of heavy metal in the soil can impair plant growth and development. Nevertheless, other changes such as enhanced urban green areas, improved habitat heterogeneity and targeted human interventions and can provide favorable conditions for plant growth. These factors influence the dynamic change and distribution pattern of urban plant diversity to different degrees in different stages of urban development. Moreover, it takes enormous amounts of time and energy to conduct comprehensive surveys on plant diversity data; as such, this arduous task cannot be properly accomplished in many cities (Niemelä, 1999; Godefroid, 2001). The data used in some studies are often incomplete (Sudnik-Wojcikowska, 1987), which can also lead to different findings. By using comprehensive data on plant species during the rapid urbanization phase of the research area, this study more clearly presents the dynamic changes in urban flora composition during the rapid urban development on a medium time scale.

\section{Changes in plant diversity and influencing factors}

Our study has revealed a significant change in the plant diversity of the research area over the past four decades. Urban biodiversity is greatly shaped by human activities, such that human decisions and behaviors impact urban biodiversity (Hope et al., 2003; Wu et al., 2011). Hangzhou has been experiencing very rapid urbanization since 1980, with significant changes taking place in its landuse patterns. For instance, the land used for construction increased from 6.85\% in 1985 to 37.84\% in 2017 (Yang et al., 2017). The resident population in the research area reached 10.36 million in 2020 . The city also welcomed 208 million travelers in 2020 (HBS, 2021). All of these factors have had a substantial impact on local plant diversity.

Over the past four decades, 101 plant species have been lost and 438 plant species have been acquired in the region, with the latter including 52 species of ornamental plants. Many factors have contributed to the disappearance of plant species, such as agricultural intensification, nitrogen input, wetland degradation, construction activities and herbicide use. Among them, the leading factor appears to be changes in land use (Gregor et al., 2012), such as decreased arable land and forests and an increase in built-up areas. The loss of plant species is also related to the way that land is used. In the three decades between 1985-2017 alone, the area of urban arable land converted into construction land and the area of forest converted into construction land reached 1008.63 ha and 949.21 ha, respectively, leading to the loss of some species that originally inhabited the arable land or forest.

Another important factor contributing to enhanced urban plant diversity is that many foreign species are introduced as ornamental plants in urban greening (Thompson et al., 2003) at a rate and amount that far exceed the loss of native species (Sax and Gaines, 2003). It should be noted that this does not completely concur with our findings. In spite 
of the significant increase in plant species in the research area, the number of acquired ornamental plants only accounts for $11.9 \%$ of the acquired total. Apparently, the added plants are mostly newly found species distributed in this region, which is most likely a result of the massive efforts in large-scale plant resource investigation in the region in recent years. Although historical surveys are already relatively adequate, omissions are still inevitable. Therefore, it is necessary to conduct in depth supplementary surveys over the longer term. The same work has been carried out in many cities across China and fruitful results have been achieved (Ma, 2008; Ding and Jin, 2017).

Invasive plants have also seen a significant increase in the research area. The number of invasive plant species increased by $34.6 \%$ in 2020 compared to 2018, which has already impacted local ecosystems (Wang, 2008; Xie et al., 2012). Invasive plants prefer dry, alkaline and warm places that are rich in nutrients and have sufficient sunlight; such conditions typically result from human beings cutting down trees and piling up construction materials, as well as global warming (Godefroid, 2001). The fragmentation of urban landscapes has also increased the risk of invasive species invading (Thomas et al., 2001). Research has found that most invasive plants come from warm areas in tropical America (Sukopp, 1997) and higher temperatures in urban areas and fragmented ecologies provide favorable conditions for invasive plants. Urban greening and horticultural exchanges have introduced a large number of species. One typical example is Solidago canadensis (Wang, 2008), which was introduced to China as an ornamental plant and has since caused serious invasive effects. As such, it is essential to monitor how the introduced species behave in order to know at the earliest possible time when they may become a "harmful" one. This will would enable allow for the more effective management of urban biodiversity so as to reduce the potential risks of associated with invasive species (Mao et al., 2013).

The past four decades have witnessed a significant change in the distribution of rare or endangered plants and national key preserved plants. On the one hand, some distribution sites close to urban areas have disappeared because of urban construction, such as the distribution sites of $M$. hangchowensis. The reduction of water bodies and the pollution of water environments have also led to the loss of the distribution sites of some rare or endangered plants such as I. sinensis and T. incisa. In the Frankfurt/Mainz region of Germany, large-scale deforestation has also led to the loss of a huge number of species (Gregor et al., 2012). On the other hand, the renewed emphasis on biodiversity conservation has contributed to the discovery of some new distribution sites of rare or endangered plants. These new sites are now well protected and play a key role in local biodiversity conservation. This also provides the basis for the implementation of species conservation and plant resource management plans (Godefroid, 2001).

\section{Ecological requirements of the urban flora}

Socioeconomic factors influence the composition and structure of urban plants through urban management, the changing of urban infrastructure and hydrological conditions (Grimm et al., 2008). A comparison of EIVs shows that the flora in the research area have changed due to urban construction. The study of the changes of urban plants in Brussels also found that newly added plants preferred places with light (Chocholouskova and Pyšek, 2003). However, urban greening has also brought about more shade, leading to an increase in the number of shade plants, which is a similar finding to that of Salinitro et al. (2019). The present study found a larger number of sun plant species than shade-tolerant

plants. This can be related to the decrease in forest and arable land and improvements in 
construction areas and open places, such as like roads and squares over the last 40 years. Among the newly added plant species, thermophiles accounted for the majority. Due to global warming, some foreign plants prefer urban areas with higher temperatures. Research has shown that the rapid urbanization in east China has led to a significant increase in urban temperatures. The temperature of the research area increased at a rate of $0.28-0.44^{\circ} \mathrm{C}$ every ten years (Xie et al., 2007; Dai et al., 2011). Whilst the irrigation in urban green areas may disrupt the effect of natural rainfall on the distribution of plant ecotypes, the increase in the number of hydrophytes has barely any correlation with irrigation. Instead, the significant increase is related to changes in urban wetland landscapes because some aquatic ornamental plants have been introduced to urban water landscapes. The development of agriculturalization entails the heavy use of fertilizers, especially phosphorus-based fertilizers, which has led to the alkalization of some areas and created favorable conditions for the growth of alkaline plants. This finding is similar to the study of Sukopp, Blume, and Kunick (Sukopp et al., 1979) conducted in West Berlin. However, plants introduced for ornamental purposes tend to prefer acidic soil, resulting in a lower soil reaction value of acquired plants in this area. Plants that are tolerant of poor soil mainly appear in areas surrounding urban construction sites, the expansion of which also provides more survival space for such plants. Furthermore, urban nitrogen deposition will lead more fertilizer-loving plants to enter the urban habitat, thus increasing the soil fertility value of acquired plants.

Perennial herbs have seen a large increase in the number of species. This is especially so among ornamental plants which have increased by $65.38 \%$. This is largely because Hangzhou, as a tourist destination, has introduced a large number of perennial ornamental herbs from home and abroad for urban greening and some plants better landscaping effects and adaptability to the local environment have been used for a long time.

\section{Significance to urban planning}

An analysis of the evolution of plant diversity not only provides information on the extent to which species numbers have changed but also offers possible reasons for such changes. Therefore, it forms the basis for landscape planning, and more importantly, decision making on species and biome conservation (Schaepe, 1990). There have increasingly been broader conservation efforts directed towards urban plant diversity of not only species, biota and ecology, but also landscapes, which has improved the living conditions of urban residents. Hence, green area planning and biodiversity conservation in urban planning essentially aim to improve the quality of urban environments. The improvement of urban environmental quality can broadly be achieved in three main ways: (a) expanding the total area of green spaces; (b) improving the quality of green spaces; (c) establishing an effective ecological network (Chocholouskova and Pyšek, 2003).

Changes in urban land use have reshaped current land patterns. Since the land used for urban construction has increased, urban planners now allocate part of this land for urban greening purposes to compensate for the reduction in arable land and forests. Studies have shown that the area set aside for urban greening is expanding at a rate larger than that of urban areas themselves (Fuller, 2009; Kabisch and Haase, 2013). As of 2020, the urban green area in Hangzhou accounts for $14.26 \%$ of the total built-up area (HBS, 2021). Urban green areas can provide more environments for plants to adapt thanks to their high habitat heterogeneity and operability in habitat construction and management. Some native plants that have disappeared can be artificially grown in urban green areas, so as to improve their plant diversity (Fan et al., 2016). However, the loss of native biodiversity 
arising from the destruction of natural habitats can hardly be recovered by expanding urban green areas in the short term. Therefore, urban planning and land use should prioritize strengthening land conservation, including its species, biota, habitats and landscapes. Urban planners should not expect to compensate for the ecological losses due to land development through urban greening. The former is more beneficial to a stable urban ecological system and will more likely promote sustainable urban development. Cities or communities with higher levels of economic and social development will use more diverse and rare plant species to improve the quality of their green areas (Aronson et al., 2017), creating a "luxury effect". Some foreign plants are typically introduced to cities as ornamental plants. As Hangzhou welcomes more frequent trade and business exchanges with other cities, its urban biodiversity will accordingly be more susceptible to foreign species. Although the introduction of foreign species is inevitable, advocating the use of native plant species for ornamental purposes in urban planning should be highlighted.

\section{Conclusions}

In this study, Hangzhou city was taken as the research area. Based on the historical data of flora for the years 1981 and 2020, the dynamic changes in plant diversity in Hangzhou over the past four decades of rapid urbanization are analyzed, with the results revealing that:

1. An analysis of the change of urban biodiversity with existing literature may help with urban planning and biodiversity conservation. In this study, the plant diversity in Hangzhou city has changed in the past four decades due to rapid urbanization.

2. The loss of plant species in Hangzhou may relate to the way that land is used. The introduction of ornamental plants is not the main factor contributing to the increase in plant species and some of these have become invasive species in this area. As new distribution sites were found for rare and endangered plants, they are now well protected and play a key role in local biodiversity conservation.

3. A comparison of EIVs shows that the flora in the study area have changed due to urban construction. The number of species that are sun plants increased more than shade plants and there was a significant increase in the number thermophilous and hepophyte plant species.

4. Urban planning and land use should prioritize strengthening land conservation, including its species, biome, habitats and landscapes, which are more beneficial to a stable urban ecosystem and will more likely promote urban sustainable development. Although the introduction of foreign species is inevitable, advocating the use of native plant species for ornamental purposes in urban planning should be highlighted.

The species diversity of urban green space is of great significance for maintaining the ecological security and balance of urban system and improving the living environment. Urban green space with high plant diversity can improve ecosystem stability and provide sustainable ecosystem services for urban residents, such as providing heterogeneous habitats and alleviating urban heat island effect. However, there is little research connecting the urban plant diversity and its ecosystem services. The research on the relationship between the structure of urban plant diversity and ecosystem function is helpful to understand the impact of the spatial pattern of urban plant diversity on the stability of urban ecosystem and ecosystem service, which is an important direction of urban plant diversity study in the future. In addition, it should also pay attention to the 
ecological risks brought by the distribution of alien species and invasive species in cities and the potential health risks brought to urban residents, so as to reduce any harm to the sustainable development of the city and provide scientific suggestions for urban planning and construction.

Acknowledgements. This work was supported by Hangzhou Science and Technology Development Project (20201203B113).

\section{REFERENCES}

[1] Angold, P. G., Sadler, J. P., Hill, M. O., Pullin, A., Rushton, S., Austin, K., Small, E., Wood, B., Wadsworth, R., Sanderson, R. (2006): Biodiversity in urban habitat patches. Science of the Total Environment 360: 196-204.

[2] Aronson, M. F., Lepczyk, C. A., Evans, K. L., Goddard, M. A., Lerman, S. B., Macivor, J. S., Nilon, C. H., Vargo, T. (2017): Biodiversity in the city: key challenges for urban green space management. - Frontiers in Ecology and Environment 15: 4.

[3] Bijoor, N. S., McCarthy, H. R., Zhang, D., Pataki, D. E. (2012): Water sources of urban trees in the Los Angeles metropolitan area. - Urban Ecosystem 15: 195-214.

[4] Chen, L. X., Duan, W. B., Zhong, C. Y., Wang, L. X. (2013): Heavy Metal Contamination Characteristics of Greenbelt Soil and Tree Enrichment in Harbin City, China. - Advanced Materials Research 610: 3080-3084.

[5] Chen, Z. H., Chen, F., Xie, W. Y., Zhang, Y. F., Li, G. Y. (2019): Additional notes on the seed plant flora of Zhejiang ( II ). - Journal of Zhejiang Forestry Science and Technology 39: 56-63.

[6] Chen, Z. H., Xie, W. Y., Chen, F., Zhu, Y. R., Jin, X. F. (2021): New notes on Acer L. in Zhejiang ( II ). - Journal of Zhejiang Forestry Science and Technology 41(3): 69-73.

[7] Chi, F. H., Liu, X., Zhang, F. Y., Pu, J. B., Chen, J. B., Chen, Z. H. (2021): Notes on the seed plant flora of Zhejiang (X). - Journal of Zhejiang Forestry Science and Technology 41(3): 79-84.

[8] Chocholouskova, Z., Pyšek, P. (2003): Changes in composition and structure of urban flora over 120 years: a case study of the city of Plzen. - Flora 198: 366-376.

[9] Dai, Y. F., Liu, Y. M., Zhou, L. J. (2011): Observation analysis of urbanization effect on surface air temperature trends in East China. - Journal of the Meteorological Sciences 31: 365-371.

[10] Ding, B. Y., Jin, C. (2017): Flora of Wenzhou (Vols.1-5). - China Forestry Publishing House, China.

[11] Ding, B. Y., Chen, Z. H., Jin, X. F., Xu, Y. L., Zhu, G. Q. (2019): A supplement to Labiatae in Zhejiang province. - Journal of Hangzhou Normal University (Natural Science Edition) 18: $18-21$.

[12] Domina, G., Galasso, G., Bartolucci, F., Guarino, R. (2018): Ellenberg Indicator Values for the vascular flora alien to Italy. - Flora Mediterranea 28: 53-61.

[13] Ellenberg, H., Weber, H. E., Duell, R., Wirth, V., Werner, W., Paulissen, D. (1991): Indicator values of plants in central Europe. - Goettingen, Germany.

[14] Fan, M. Y., Pan, K. X., Han, W. J., Lu, Y. J., Shen, Q., Wang, M., Ren, Y., Qu, Z. L., Chang, J., Ge, Y. (2016): A strategy for introducing an endangered plant Mosla hangchowensis to urban area based on nitrogen preference. - Acta physiologiae Plantarum 38: 265.

[15] Fu, L. G., Chin, C. M. (1992): China Plant Red Data Book: Rare and Endangered Plants. Science Press, China. 
[16] Fudali, E. (1995): Changes in the bryoflora of urban areas. A case study of Lesne Wzgorze in Szczecin (NW Poland). - Fragmenta Floristica et Geobotanica Polonica 40: 311-321.

[17] Fuller, R. A., Gaston, K. J. (2009): The scaling of green space coverage in European cities. - Biology letters 5: 352-355.

[18] Godefroid, S. (2001): Temporal analysis of the Brussels flora as indicator for changing environmental quality. - Landscape and Urban Planning 52: 203-224.

[19] Gregg, J. W., Jones, C. G., Dawson, T. E. (2003): Urbanization effects on tree growth in the vicinity of New York City. - Nature 424: 183-187.

[20] Gregor, T., Bönsel, D., Starke-Ottich, I., Zizka, G. (2012): Drivers of floristic change in large cities - A case study of Frankfurt/Main (Germany). - Landscape and Urban Planning 104: 230-237.

[21] Grimm, N. B., Grove, J., Pickett, S. T., Redman, C. L. (2000): Integrated Approaches to Long Term Studies of Urban Ecological Systems. - BioScience 50: 571-584.

[22] Grimm, N. B., Faeth, S. H., Golubiewski, N. E., Redman, C. L., Wu, J., Bai, X., Briggs, J. M. (2008): Global change and the ecology of cities. - Science 319: 756-760.

[23] Hangzhou Bureau of Statistics (HBS). (2021): Hangzhou Statistical Yearbook. - China Statistic Press, China.

[24] Hope, D., Giles, C., Zhu, W. X., Fagan, W. F., Redman, C. L., Grimm, N. B., Nelson, A. L., Martin, C., Kinzig, A. (2003): Socioeconomics drive urban plant diversity. - PNAS 100: 8788-8792.

[25] Hortus Botanicus Hangzhouensis (HBH). (1982): Enumeratio plantarun vascularium civitatis Hangzhou. - Mimeographed Booklet, China.

[26] Kabisch, N., Haase, D. (2013): Green spaces of European cities revisited for 1990-2006. Landscape and Urban Planning 110: 113-122.

[27] Kaye, J. P., Groffman, P. M., Grimm, N. B., Baker, L. A., Pouyat, R. V. (2006): A distinct urban biogeochemistry? - Trends in Ecology \& Evolution 21: 192-199.

[28] Kent, M., Stevens, R. A., Zhang, L. (2001): Urban plant ecology patterns and processes: a case study of the flora of the City of Plymouth, Devon, U.K. - Journal of Biogeography 26: 1281-298.

[29] Knapp, S., Kuhn, I., Static, J., Klotz, S. (2010): Changes in the functional composition of a Central European urban flora over three centuries. - Perspectives in Plant Ecology Evolution and Systematics 12: 235-244.

[30] Kowarik, I. (2011): Novel urban ecosystems, biodiversity, and conservation. Environmental Pollution 159: 1974-1983.

[31] Landolt, E. (2000): Some results of a floristic inventory within the city of Zürich. - Preslia 72: 441-455.

[32] Li, G. Y., Wang, J. F., Xie, W. Y., Zhang, Y. F., Mei, X. D., Chen, Z. H. (2021): Additional notes on the seed plant flora of Zhejiang (VIII). - Journal of Zhejiang Forestry Science and Technology 41: 40-46.

[33] Lososová, Z., Simonová, D. (2008): Changes during the 20th century in species composition of synanthropic vegetation in Moravia (Czech Republic). - Preslia 80: 291305.

[34] Loughner, C. P., Allen, D. J., Zhang, D. L., Pickering, K. E., Dickerson, R. R., Landry, L. (2012): Roles of urban tree canopy and buildings in urban heat island effects: parameterization and preliminary results. - Journal of Applied Meteorology and Climatology 51: 1775-1793.

[35] Lovett, G., Traynor, M., Pouyat, R., Carreiro, M., Zhu, W. X., Baxter, J. (2000): Atmospheric deposition to oak forests along an urban-rural gradient. - Environmental Science \& Technology 34: 4294-4300.

[36] Ma, J. S. (2013): The checklist of the Chinese invasive plants. - High Education Press, China.

[37] Ma, D. D. (2018): Atlas of plants in Ningbo. - Science Press, China. 
[38] Mao, Q. Z., Ma, K. M., Wu, J. G., Tang, R. L., Zhang, Y. X., Luo, S. H., Bao, L., Cai X. H. (2013): An overview of advances in distributional pattern of urban biodiversity. - Acta Ecologica Sinica 33: 1051-1064.

[39] McKinney, M. L. (2006): Urbanization as a major cause of biotic homogenization. Biological Conservation 127: 247-260.

[40] National Forestry Administration (NFA). (1999): List of national key protected wild plants (the first batch). - Plants 5: 3-11.

[41] Niemelä, J. (1999): Ecology and urban planning. - Biodiversity Conservation 8: 119-131.

[42] Niinemets, Ü., Peñuelas, J. (2008): Gardening and urban landscaping: significant players in global change. - Trends Plant Science 13: 60-65.

[43] Pärtel, M., Zobel, M., Zobel, K., van der Maarel, E. (1996): The species pool and its relation to species richness: evidence from Estonian plant communities. - Oikos 75: 111-117.

[44] Pickett, S. T. A., Cadenasso, M. L., Grove, J. M., Nilon, C. H., Pouyat, R. V., Zipperer, W. C., Costanza, R. (2001): Urban ecological systems: Linking terrestrial ecological. Physical, and socioeconomic components of Metropolitan Areas. - Annual Review of Ecology and Systematics 32: 127-157.

[45] Sal'nikov, A. L., Pilipenko, V. N. (2005): Anthropogenic transformation of flora in the city of Astrakhan and its environs over the past 100 years. - Russian Journal of Ecology 36: 383-390.

[46] Salinitro, M., Alessandrini, A., Zappi, A., Tassoni, A. (2019): Impact of climate change and urban development on the flora of a southern european city: analysis of biodiversity change over a 120-year period. - Scientific Reports 9: 1-10.

[47] Sax, D. F., Gaines, S. D. (2003): Species diversity: From global decreases to local increases. - Trends in Ecology \& Evolution 18: 561-566.

[48] Schaepe, A. (1990): Grid mapping of bryophytes in Berlin (West). - In: Sukopp, H., Hejny, S. (eds.) Urban Ecology: Plants and Plant Communities in Urban Environments. SPB Academic Publishing, Den Haag, The Netherlands.

[49] Song, Y. C., Wang, X. H., Yan, E. R. (2013): Evergreen broad-leaved forest in China: classification, ecology, conservation. - Science Press, China.

[50] Song, Y. C., Yan, E. R., Song, K. (2015): Synthetic comparison of eight dynamics plots in evergreen broadleaf forests, China. - Biodivestry 23: 139-148.

[51] Sudnik-Wojcikowska, B. (1987): Dynamik der Warschauer flora in den letzten 150 Jahren. - Gleditschia 15: 7-23.

[52] Sukopp, H., Blume, H. P., Kunick, W. (1979): The soil, flora and vegetation of Berlin's waste lands. - In: Laurie, I. C. (ed.) Nature in Cities. Chichester, UK.

[53] Sukopp, H. (1997): History of the flora and vegetation of Berlin and their conservation. Journal d'agriculture traditionnelle et de botanique appliquée 39: 265-283.

[54] Sukopp, H. (2002): On the early history of urban ecology in Europe. - Preslia 74: 373-393.

[55] Tait, C. J., Daniels, C. B., Hill, R. S. (2005): Changes in species assemblages within the Adelaide Metropolitan Area, Australia, 1836-2002. - Ecological Applications 15: 346-359.

[56] Thomas, C. D., Bodsworth, E. J., Wilson, R. J., Simmons, A. D., Davies, Z. G., Musche, M., Conradt, L. (2001): Ecological and evolutionary processes at expanding range margins. - Nature 411: 577-581.

[57] Thompson, K., Austin, K. C., Smith, R. M., Warren, P. H., Angold, P. G., Gaston, K. J. (2003): Urban domestic gardens (I): Putting small-scale plant diversity in context. - Journal of Vegetation Science 14: 71-78.

[58] Vico, G., Revelli, R., Porporato, A. (2013): Ecohydrology of street trees: design and irrigation requirements for sustainable water use. - Ecohydrology 7: 508-523.

[59] Wang, N. X. (2008): Simple Study on Plants of Adventitious Invasion in Hanzhou City. Forest Inventory and Planning 33: 125-128.

[60] Wu, Z. Y. (1991): The areal-types of the Chinese genera of seed plants. - Acta Botanica Yunnanica S IV: 1-139. 
[61] Wu, J. G., Jenerette, G. D., Buyantuyev, A., Redman, C. L. (2011): Quantifying spatiotemporal patterns of urbanization: the case of the two fastest growing metropolitan regions in the United States. - Ecological Complexity 8: 1-8.

[62] Wu, Z. Y., Raven, P. H., Hong, D. Y. (2013): Flora of China (Vols. 2-25). - Science Press, China; Missouri Botanical Garden Press, USA.

[63] Wu, S., Pan, F. M. (2014): SPSS statistical analysis. - Tsinghua University Press, Beijing.

[64] Xie, Z. Q., Du, Y., Zeng, Y., Shi, Y. F., Wu, J. G. (2007): Impact of urban expansion on regional temperature change in the Yangtze River Delta. - Journal of Geographical Sciences 62: 717-727.

[65] Xie, G. X., Xu, Z. H., Chen, W. M., Yuan, X. F. (2012): The Invasive and spread patterns, harmfulness, countermeasures of exotic harmful plants in Hangzhou district. - Journal of Agricultural Catastrophology 2: 37-41.

[66] Xie, W. Y., Chen, F., Zhang, F. Y., Xu, S. Q., Liu, J. L., Chen, Z. H. (2019): Additional notes on seed plant in Zhejiang province. - Journal of Zhejiang Forestry Science and Technology 39(1): 86-90.

[67] Yan, X. L., Wang, Z. H., Ma, J. S. (2019): The checklist of the naturalized plants in China. - Shanghai Science and Technology Press, China.

[68] Yang, Y. F., Jin, P. B., Zhu, X. Y. (2017): Change of land use in process of urbanization in Hangzhou during past 30 years. - Journal of Zhejiang University (Engineer Science edition) 5: 1462-1474.

[69] Yu, J. L., Lu, Y. J., Jin, X. F., Fu, C. X. (2017): Flora of Hangzhou (Vols. 1-3). - Zhejiang University Press, China.

[70] Zang, D. K. (1998): A Preliminary study on the ferns flora in China. - Acta Botanica Boreali-Occidentalia Sinica 18: 459-465.

[71] Zhang, W., Feng, Z., Wang, X., Niu, J. (2012): Responses of native broadleaved woody species to elevated ozone in subtropical China. - Environmental Pollution 163: 149-157. 